This is a self-archived version of an original article. This version may differ from the original in pagination and typographic details.

Author(s): Horsti, Karina

Title: Transnational Mediated Commemoration of Migrant Deaths at the Borders of Europe

Year: 2019

Version: Accepted version (Final draft)

Copyright: ㄷ 2019 John Wiley \& Sons, Inc.

Rights: In Copyright

Rights url: http://rightsstatements.org/page//nC/1.0/?language=en

Please cite the original version:

Horsti, K. (2019). Transnational Mediated Commemoration of Migrant Deaths at the Borders of Europe. In J. Retis, \& R. Tsagarousianou (Eds.), Handbook of Diasporas, Media, and Culture (pp. 193-205). John Wiley \& Sons. https://doi.org/10.1002/9781119236771.ch13 


\title{
13. Transnational mediated commemoration of migrant deaths at the borders of Europe
}

\section{Karina Horsti}

Pre-publication copy of a chapter

Horsti, Karina (2019) Transnational mediated commemoration of migrant deaths at the borders of Europe in Retis, Jessica \& Tsagarousianou, Roza (eds.) The Handbook of Diasporas, Media, and Culture, Wiley-Blackwell.

\begin{abstract}
More than 30000 people have died at Europe's borders between 1993 and 2018. These tragedies touch family members and diasporic communities across the globe. While these deaths are often invisible in the mainstream media - they are not ritualized as common loss this does not mean that media would not play a crucial role in commemoration among diasporic communities directly affected by the loss. Facebook groups, websites, and selfmade You Tube videos are examples of transnational mediated commemoration that brings together mourners across distances. By asking, how diasporic communities commemorate border related death, this chapter identifies and theorizes a previously unexplored research area, that of transnational commemoration of border death. The empirical research focuses on the Eritrean diaspora for whom the shipwreck known as the Lampedusa tragedy of 2013 has become an important lieux de memoiré. The chapter shows how the new media technology shapes commemoration in ways that challenges politics, both in Europe and in Eritrea.
\end{abstract}

\section{Keywords}

Border, memory, remembering, refugees, asylum seekers, transnationalism, activism, humanitarianism, social media, digitalization

\section{Introduction}

Collective remembering is crucial for social power dynamics, as it often reflects the dominant narratives of a group or a nation. Public commemorative performances such as vigils, moments of silence, speeches, and laying wreaths are signs of social recognition; by 
representing certain social groups, individuals, or events as worthy of common mourning, these rituals highlight their social importance. From a Durkheimian sociological perspective they can be seen as symbolic rituals that communicate shared values within a group in order to reduce social instability (Connerton, 1989, p. 49). As the past is always remembered in the context of the needs of the present (see e.g. Neumann, 2000; Erll \& Rigney, 2012), commemoration also serves the needs of the mourning community. One function of commemoration can be to bring a community together and to help the community 'move on' from a state of loss and confusion. Therefore, rituals of remembrance can be as much about forgetting as they are about remembering, which underlines that memory and forgetting are co-constitutive and essential to each other's existence (Sturken, 1997: 2). Media scholars argue that in mediatized and digitalized societies these rituals are increasingly done in and through the media (Sumiala 2013), leading to an abundance of death in the media. As death has been cleared out of the everyday experience and wiped from view in the homes and public places of Western societies, the media has become the domain where issues of loss and existence are discussed (Lagerkvist 2013; Haverinen 2014).

More than 30000 people died at Europe's borders between 1993 and 2018, and 5000 people in 2016 alone. The remembrance of these disasters cuts across private and public practices of mourning in complex ways that have not yet been fully explored in media or memory studies. In present-day digitalized societies, two trends in mediated mourning have been identified: publicizing private losses, mainly online, has increased and dead individuals who were not personally known and who are not linked to a 'national sacrifice', such as war, are being commemorated (Lagerkvist, 2013).

It is my intention in this chapter to examine the remembrance of the deaths of migrants at the European border in the context of these broader trends in coping with death and loss in mediated societies. The fact that those who died were not citizens of the place in which they died complicates the thinking on memory and community. The deceased were aspiring to become citizens, and most of them had close connections to people who are residents or citizens of European nations. They were not complete strangers to Europe, but were known through diasporic connections. Many would have gained the right to stay in Europe if they had survived and applied for asylum. Thus, we need to ask what is the community that is searching for social cohesion through the commemoration of those who died at Europe's borders. Moreover, I examine the roles media play in the commemoration and 
memorialization of these deaths. In doing so, this chapter identifies and theorizes a previously unexplored research area in media and communication research - transnational and mediated commemoration of death at European borders.

The chapter is divided into the analyses of three different kinds of mourning communities and their commemorative practices. In the first section of the chapter, I examine how European, national and local leaders have responded to border fatalities with dual, co-existing responses: ignoring the deaths and mediatized commemoration. Second, I analyze grief activism by artists, human rights activists and humanitarian agents. In the third part of the chapter, I look at diasporic mourning communities and the ways in which they create new methods of commemoration in the context of various absences and distances. In analyzing different types of commemorations (and the lack of commemoration) of border-related deaths, the chapter identifies public mourning agents and their relations. These include European, national, and local leaders, human rights activists, critical border activists, survivor-victim communities and diasporic communities.

This chapter draws on empirical research from the project Remembering migration: Memory politics of forced migration in mediated societies (Karina Horsti, Academy of Finland 2014 2019). Using multi-sited ethnography and mobile methods, I have interviewed activists who rescue migrants in the Mediterranean Sea and protest groups that act against human rights violations and border control. I have analyzed memorials and commemorations in Italy and beyond using both offline and online ethnography. A core part of the research focuses on the 3 October 2013 shipwreck, known as the Tragedy of Lampedusa, in which at least 368 mainly Eritrean migrants died and 155 survived. I have analyzed the media coverage of the shipwreck and its memorialization in art and activism. I have participated in anniversary commemorations in Lampedusa and interviewed local people who were involved in the aftermath of the disaster. I have also interviewed Eritrean-Swedish human rights activists and seven Eritrean survivors who live in Sweden. The research material also includes various online memorials such as amateur YouTube videos and vernacular expressions of mourning on Facebook.

\section{Power dynamics in public commemoration and memorialization}

Dead bodies discovered in European border zones are often buried anonymously and without ceremony in mass graves. While this is still the case for most burials in Italy, the Tragedy of 
Lampedusa altered the commemorative landscape by prompting memorial rituals across Europe. European leaders flew to Lampedusa to mourn, the Italian government organized an official 'funeral', commemorative rituals have attracted political and media attention on the three anniversaries of the event to date, and in 2016 Italy declared 3 October as the official day of commemoration of 'victims of immigration'.

The coexistence of the visibility and invisibility of border-related deaths and the public mourning of them is apparent in the cemetery in Catania, Sicily, that I visited in September 2015. While the central Mediterranean route has been fatal to migrants for the past 15 years, there had been no visible signs of memorialization in Catania before 2015. On 10 March 2015, the city inaugurated a memorial entitled La speranza naufragata [Wrecked Hope] in the main cemetery in Catania, which functions in two ways. First, the memorial is a critique of the European Union, which from the Sicilian perspective does not take enough responsibility for irregular migration, leaving the region to handle fatalities on its own. Large shipwrecks have offered a stage for Italy's demands for resources to be heard: six days after the 3 October 2013 shipwreck, the president of the European Commission, José Manuel Durāo Barroso, flew to Lampedusa to commemorate the victims and to announce that Italy would receive an additional 30 million euros from other European countries. In this European dynamic, commemoration functions as a way to obtain resources to manage the border.

Second, the memorial also serves to create a positive self-identification for Sicilians as a caring society in the spotlight of international media attention. The creation of the memorial and the commemorative rituals that it invites are responses to the encounter with mass death and its aftermath. The 'humanitarian imaginary' (Chouliaraki, 2013) crucially shapes the way in which people are expected to respond to suffering and death at European borders.

The speech given by the mayor of Catania, Enzo Bianco, at the funeral and inauguration ceremony at the cemetery highlights both of these points: 'I remember how as a child many of our fellow inhabitants left Sicily to seek their fortunes. This image came to mind when I saw the stories of these people who searched for hope but didn't make it. Catania is a generous city and today it proved it, but we also gave the European Union a warning. We ask not to be left alone to manage this.' (Gangi, 2015.) In addition to his political appeal to the European Union, Bianco also produces an identity of hospitality for the people of Catania, an identity that is based on their own experience as immigrants. In this way, he seeks empathy 
through similarity: both the victims and the Sicilians are seen as outsiders and as sharing the migrant experience.

At the center of the Catania memorial stands a sculpture of two figures on top of what could be waves or fire. Seventeen horizontal tombstones lay around the sculpture. The stones do not have names, but each is engraved with a verse from the Nigerian author Wole Soyinka's poem 'Migrations'. The memorial is anonymous; there is no indication of who is buried there or when the bodies were found, and therefore it becomes a generic memorial of borderrelated death, rather than a place to grieve the specific people buried there. Nevertheless, there are 17 bodies buried in this site. The media coverage of the cemetery's inauguration revealed that the Nigerian, Syrian and Eritrean people buried in the tomb below the memorial were victims of a shipwreck on 15 May 2014, but their names are not mentioned, nor is it explained why there are no names on the memorial, as there are on the Italian tombstones. Naming victims and investigating their life stories and hopes is a standard practice in news coverage of catastrophes in which Europeans die and in the memorialization of those catastrophes. The generic nature of the memorial is further underlined in the subsequent media coverage about the memorial. It is often mistakenly taken as a remembrance of another tragedy: the highly mediatized shipwreck that happened close to Libya on 18 April 2015, in which about 800 migrants died.

Material manifestations of public remembrance such as the La speranza naufragata memorial are not guarantees that border-related deaths will be remembered and commemorated after their inauguration. Actually, monuments are often easily overlooked and they become 'invisible'. They may not have much effect on the surrounding community if they do not attract rituals and performances. (Neumann, 2000, pp. 4 -5.)

The lack of attention to the identity of the victims is even more evident nearby, at the edge of the cemetery, where I found a row of burial mounds that are marked only by coded signs. The signs have three codes, indicating that three corpses are buried under each mass of earth. There is no sign explaining the site and no evidence of any commemorative rituals. Locals taking care of their daughter's grave nearby told me that this is the burial ground of the clandestini, 'the illegals', who are regularly and unceremoniously buried there. One of the mounds has a tombstone marked with a name and stones placed around it. This one Syrian man had relatives who had the resources to carry out a funeral. 
The silent ungrievability (Butler 2009) and invisibility of these burials and the lack of sensitivity towards diasporic communities and family members are routine practices in European border zones. Sometimes, however, this inattention is broken with mediatized attention. In these mediatized performances, multiculturality is incorporated in a tokenistic manner: the local Muslim religious leaders and some people from the survivor-victim community are invited. On the edge of the memorial in Catania stands a memorial stone placed by Sicily’s Muslim community.

When European governments, Frontex, and other institutions that contribute to the production of bordering also commemorate migrant death, it is easy to condemn their commemorations as the instrumentalization of grief - 'a schizophrenic' spectacle that reproduces 'a humanitarian imaginary of Europe in the very moment of burying its border fatalities' (Stierl 2016, p. 189). In this context, commemoration by European leaders emerges from a humanitarian imaginary that positions European institutions as caring agents. In these types of performances, migrants are seen as helpless victims - non-agents to the extent that even in the moment of death, no one cares to know their names and identities or is concerned about their family members' right to mourn. Furthermore, the humanitarian imaginary conceals the border mechanisms, such as visa policies, border surveillance, and tightened family reunification, that force people to take dangerous routes. Commemoration creates an illusion of 'humanitarian bordering', in which shipwrecks are unfortunate events in a practice that otherwise exists to 'save lives'.

The duality in the response to border deaths that can be read in the landscape of the Catania cemetery is criticized by many of those who have to deal with these deaths. Commemorative rituals and monuments easily become sites of contestation and politics (about migrant deaths, see e.g. Stierl 2016; Weber \& Pickering 2011, p. 76). One such critic is Marco Zambuto, the mayor of Agrigento, Sicily, who criticized the commemorative service organized by the state of Italy for the victims of the 3 October 2013 shipwreck as a 'farce' and a 'photo opportunity for [Minister of the Interior Angelino] Alfano' (Deutche Welle, 2013). Another critic is the mayor of Lampedusa, Giusi Nicolini (2015). Nicolini declined to participate in the official funeral ceremony in Agrigento, to which the survivors were not invited. Instead, the municipality of Lampedusa and the survivors of the shipwreck planted 366 plants as a memorial garden. In the context of a contested commemorative landscape, the performance 
of planting functioned as a criticism against official, 'inauthentic' commemoration. Even before this, the municipality had organized funerals for unidentified bodies at the local cemetery.

Judith Butler (2009, p. xix) argues that people tend to value death differently depending on the circumstances of death and on the category of the deceased person: some are treated as more publicly grievable than others. When Europeans die unexpectedly, individuality (the names and details of those who died) as well as responsibility (why did this tragedy happen and how it could be prevented) are standard modes of address. In the case of migrant deaths, we need to ask, what are the frames that produce 'ungrievability' of irregular migrants at European border zones. In the Western mediated circulation, some lives and deaths are depicted as 'ungrievable' because ontologically these lives are perceived as being already lost before death. For instance, suffering and death are depicted as normal conditions for people who come from war-torn countries or the imaginary totality of 'Africa'. As a result, Europeans don't experience the deaths of migrants at the borders as a real tragedy. Moreover, while European mainstream and activist media regularly witness migrant deaths in the Mediterranean, paradoxically, the circulation of images of boatloads of suffering migrants also normalizes these deaths and de-sensitizes the viewer to death. It presents death as a regular feature of irregular migration - something that is simultaneously an exceptional emergency and a 'naturalized' phenomenon experienced by the Other. The treatment of migrants as an anonymous mass in Europe - even in the rare cases of memorialization reflects the assumption that there are no life stories or family relations to be uncovered and to be used to create a figure of a human who could be remembered.

In addition to such Euro-centric response to border fatalities, there is another hegemonic approach to consider in the context of border fatalities: the mainstream response to migrant deaths in the migrants' countries of origin. The places that migrants and refugees leave to risk their lives in European border zones have different official approaches to these deaths. My research indicates that in the case of Eritrea, the totalitarian regime wants to ignore the deaths in order to avoid the fact that more than 320000 Eritreans have fled the country (UNHCR 2016). For the regime, refugees are traitors of the nation. For instance, Eritrean national television didn't mention that the dead were from Eritrea and this was widely condemned by Eritreans abroad and the oppositional groups. 


\section{Mourning in activism: counter-remembrance of death in the border zone}

In the previous section I outlined some of the contestations that have taken place between local, regional, national, and European officials around the commemoration of shipwrecks in Italy. As a mode of communication, commemoration is performative, and therefore cannot be fully scripted (Taylor, 2003). Commemoration is always unsettled and dynamic; it is a site of contestation and negotiation in the juncture of hegemonic narratives and critical interpretations of what happened. This is especially the case in societies where participatory culture affords different kinds of 'mnemonic resistance' to dominant narratives (Ryan, 2011). Such mnemonic resistance can be generated by those who are intimately touched by the events that are remembered or by those who did not personally experience the event or know the deceased.

There are two directions from which public counter-remembrance of border-related deaths emerges: from the refugee and diasporic communities and from human rights activist groups, often led by Europeans. Recent scholarship has examined the latter type of grief activism the European-led public and critical mourning of death and its production of solidarity between migrants and Europeans (see e.g. Stierl, 2016; Rygiel, 2016). However, I would argue that public mourning and its role in human rights activism in diaspora and transnational migrant activist communities is a crucial form of grief activism that needs more attention.

For example, Eritrean diasporic commemoration, including both public rituals and online memorials, is characterized by the human rights struggles and political opposition to the Eritrean regime that has forced the people to leave the country (Estefanos, 2016). To a lesser extent, these commemorations are also struggles against the European border regime. For the refugee diaspora, there is a complex attitude towards the countries that have offered them protection but which also have produced the fatal border. Thus, while commemorative performances act to counter hegemonic silence in Europe, the target of protest is often the Eritrean regime. Counter-memorialization and protests of grief that expose the violence in Eritrea may instrumentalize grief for political ends. Nevertheless, these politics are grounded in solidarity with the victims and their motivation to flee.

Artists, human rights activists, NGOs and volunteer hospitality groups have also raised public consciousness of border fatalities through commemorative performances (Stierl, 2016; Rygiel, 2016). For instance, the German private humanitarian NGO Sea Watch, which 
rescues migrants in the Mediterranean, regularly integrates commemoration into their public action. The chairman of Sea Watch, Harald Höppner, used an appearance on a live German television talk show to stage a commemoration of migrants who had died in the Mediterranean Sea earlier the same day. Höppner interrupted his interview with the host, Günther Jauch, by walking onto the stage and saying: 'Germany should dedicate one minute to commemorate these people. Now. Please.' (Bild, 2015.) People in the audience and the guests on stage stood up and participated in the ritual, interrupting the show with a broadcasted moment of silence in the television studio. The Sea Watch media team simultaneously launched a social media campaign via Twitter to amplify the commemorative performance and to frame the moment in their own terms. The counter-action turned into a public debate, first in social media, and then in mainstream media. Through this incident, the newly-established Sea Watch became known in Germany (Neugebauer, 2016).

A year later, Sea Watch released a video through social networks that showed one of their ships lowering the flag to half-mast in commemoration of a 16-year-old girl who had died on board soon after her rescue. The medic of the crew turned the moment of commemoration into activism against border management by speaking directly to the camera, saying: 'She died because she can't just buy a ticket on a plane or on a boat to come here like any of us can go anywhere through the world. She died because she's black and from Africa. She has a right to come here and seek asylum and we should be supporting these people.' (Sea Watch, 2016.)

In both of these commemorative rituals, Europeans who have witnessed border death in their volunteer work perform their grief through mediation. The imagined audience of these performances is a European one: the 'we' who can travel globally and the 'Germany' that observes a minute's silence. They are communications to donors, who through the act of commemoration are invited to join the humanitarian effort.

In addition to activists, several artists have combined memorialization and critical action against border management. The Chinese dissident artist Ai Weiwei used life jackets collected from the Greek islands in his spectacular installations in public spaces in European cities, and the Finnish German-based artist HMJokinen created an installation, 'On that Third of October', in a bunker in Hamburg in 2014. In the installation, she used materials she had found on the shores and in the boat cemeteries of Lampedusa. These kinds of works, which 
re-use discarded objects collected from the border zone and exhibit them inside the European Union, re-territorialize the border in ways that have critical potential to prompt re-thinking of the European responsibilities in the production of the deadly border. The border and its human cost are made visible in places that are geographically far from the border zone but which nevertheless are part of its production. Through the Schengen agreement, the external border of countries like Germany actually extends to the Mediterranean. By making symbols of the deadly border visible for those who do not otherwise encounter the outcomes of their governments' policies, these works prevent cultural amnesia towards border fatalities.

\section{Absences and mourning: commemorative rituals in the diaspora}

The commemorative rituals examined so far in this chapter have been performances targeted to broader audiences: global audiences, European citizens, possible donors, the Eritrean refugee diaspora, and Eritrean regime supporters. In this last section, I turn to the ways in which families and groups that have been touched intimately by border deaths mourn and memorialize those who lost their lives.

The mourning of migrant deaths among diasporic groups is shaped by several types of absences. Often, there are no bodies, or if there are bodies, their identities are not known. Even if the body is identified, the burial site is not always accessible to mourners. The family members of those who aspired to migrate to Europe may be dispersed across the world, and may not be able to obtain visas to visit the grave or to organize and pay for the return of the body. Even in the case of the 3 October 2013 shipwreck, in which the survivors were able to provide the names and personal details of those who had died, most bodies remain unidentified three years after the tragedy. The bodies are buried in various cemeteries across the Agrigento region in Sicily, in places that are difficult to reach. The impossibility of traditional funerals and the inaccessibility of memorial sites has led Eritreans to mourn in new, creative ways.

Social and mobile media technologies play an important role in connecting mourning communities across long distances. Digital images, verses from the Bible and the Quran, memories, poems, images and videos of individual commemorative rituals, and YouTube video collages of news images and family photographs are examples of transnational mediated commemoration. These mediated memorials are intended to comfort friends and family, but because of their shareability, they sometimes reach more public and activist 
commemorative spheres. Digitization increases the plasticity of photographs and videos in ways that result in the blurring of the boundaries of private and public mourning.

Digitalization blurs the boundaries between intended or planned, and un-intended or spontaneous memorialization. Facebook profiles of the deceased often turn into un-intended memorial sites (Haverinen 2014, p. 68) as people post their messages of grief on the site.

Digitalization also blurs the boundary between the living and the dead. One affordance of social media such as Facebook is that online profiles stay 'alive' even after death if no one deletes the page, extending into a digital afterlife beyond death (Lagerkvist, 2013). Users often post memorials on the Facebook walls of the deceased. In addition, Facebook groups for survivors and the family members of victims create a mourning community that 'keeps alive' a certain connection with the deceased. The form of address used in the memories shared on Facebook can be second-person singular - as if the person still had a presence and could listen. In one such Facebook group, the photograph of a woman who died in the Mediterranean receives responses such as: 'Ah, my sister, you were such a kind person, may God receive you in heaven.'

These Facebook comments are not about comforting those who live, or about forgetting and 'moving on', but they create a connection between the living and the dead and seek to keep the dead, or the memory of the dead, as part of life. In so doing, mediated memorials can shape the everyday lives of mourners by extending the shared practice of remembering. These mediated forms of remembering can make the memorial site visible when it may otherwise be absent or distant. They can also make the act of remembering a visible and recurring shared practice that is part of daily life.

The role of digital communication in mourning is further emphasized by the mourners' lack of material memory objects and the inaccessibility of memorials. In addition, there are social media groups for mourning missing people, who may have died in the Mediterranean or en route to Libya. In these cases, even the confirmation of death is absent. Mourning and the hope of finding the missing person co-exist in this liminal stage between life and death.

Social media networks facilitate the creation of different kinds of public and semi-public transnational mourning communities online. The responses to the photograph of the woman also triggered a comment from one of her family members: 'Thank you for your kind words. 
I hope a disaster like this and what we are now going through will not happen to you.' This response reflects how sharing messages of remembrance creates a mourning community online. Although all the other responses to the photograph are directed to the dead woman, their presence in the semi-public sphere of the Facebook group also reinforces caring relationships between the living.

The transnationalization and digitalization of mourning has also transformed the way in which people learn about family members' deaths. The pace of information flow and the intensity of mobile media in the daily lives of Eritreans in Europe can be greater than that of those living elsewhere, and this produces asymmetries that disturb tradition. This topic is widely discussed and debated within the Eritrean diaspora because traditionally the news of a death is delivered in person to the immediate family of the deceased. All of the Eritreans I interviewed told anecdotes of families who had been upset by the way in which they received the news of a death. Information travels faster among refugees who have reached Europe than among those who are in Eritrea, in refugee camps outside Europe, or on their escape route. Sometimes, close relatives have heard the bad news from Facebook, which could happen in circumstances where there is no emotional support available. A result of this is that Eritreans regularly post reminders in Facebook groups that members should be sure that the immediate family knows before posting any commemorative photos or messages online. These online conversations reflect the need to negotiate media practices in the context of new technologies and a transnational diaspora. The issue is how to incorporate media into everyday life in such a way that media practices create transnational and cosmopolitan solidarity and allow for the continuity of some traditional practices.

Because migrant families are dispersed, the digitization of memorial objects, such as photographs, has become common. Photographs, which were often taken in a studio in Eritrea, are digitized and shared among transnational family networks. In digitized form, these objects easily spread beyond the immediate family to other memorial groups and into memorial music videos. Private family photographs move to the public sphere and often become part of grief activism against the Eritrean regime. However, after crossing distances, digitized memory objects can also be re-materialized. Family members in the diaspora may print photographs that have been shared digitally and display them in their home. Mourning communities also turn these digitally shared photographs into posters. Survivors of the Lampedusa shipwreck collected photographs of victims from Facebook and a faith-based 
group in Italy printed a poster that was displayed in the commemorative anniversary ceremony in the church of Lampedusa a year later.

The ways in which digitalization and social media transform mourning in Eritrean diasporic communities resemble the changes in globalized and digitalized societies more broadly. New media technology has arguably changed media practices, taking them in a more individualized and participatory direction (Papacharissi, 2011) that also shapes how people commemorate the deceased. Michael Rothberg (2010, p. 9) argues that remembering is shifting from fixed memory sites, lieux de memoire (Nora, 1989), to nodes in rhizomatic networks of memory. Digital spaces and sites become important nodes in this rhizomatic memorial constellation, specifically in situations where there are no memorial places or physical human remains (see e.g. Horsti, 2017).

\section{Conclusion}

Commemoration as a mode of communication is open to contestations and negotiations among the various mourning agents related to a particular fatal event. It creates a space for negotiating the politics of responsibility. For political leaders, commemoration may be a strategy to create a humanitarian self-understanding that directs questions of responsibility elsewhere. For activists - either Europeans or those with a refugee background commemoration is also a form of protest. Through the mediation of grief, different mourning communities produce identities for themselves and others. These identity positions include humanitarian identification for the Europeans, who in the context of grief also remember those they rescued.

Those who resist regimes that force people to flee and those who oppose European migration regimes that prevent safe passage create dissident identities by commemorating border fatalities. Both for political leaders and for activists, mediatization shapes how they commemorate the dead: rituals are performances targeted at certain audiences and they need to be seen to be effective.

For diasporic mourning communities, media play a different role. Mediation, particularly in digital form, becomes crucial for transnational commemoration as the mourners are dispersed across the world. Through mediation, social media networks allow commemoration and memorials in circumstances in which the absence of mourners, bodies or memorial sites 
prevails. While these deaths are often invisible in the mainstream media - they are not ritualized as a common loss - the media plays a crucial role in commemoration among diasporic communities directly affected by the loss. Facebook groups, websites, and YouTube videos are examples of transnational mediated commemoration that brings mourners together across long distances.

This chapter has demonstrated that commemoration should be examined as a practice capable of serving several different politics: human rights, humanitarian, national, ethnic or regional identity politics. Ethically, the most relevant question is how commemoration can best support those who are intimately touched by border fatalities. And could commemoration as a form of communication advance the making of a more just society, in which those dying in the Mediterranean would not be ignored or instrumentalized for political gain, but rather seen as one of 'us', worthy of common grief? In each of the mourning communities, I have identified moments of solidarity towards the victims and the survivors. The local political leaders of the border zone have expressed compassion in their commemorative practices and protests. Political activists go beyond grief by raising awareness of the root causes of migrant deaths. And finally, by mourning together, the Eritrean diaspora creates a mourning community that is politically relevant.

Acknowledgments: The author thanks Adal Neguse and Ilaria Tucci for their research assistance, and Klaus Neumann for his insightful comments.

\section{References}

Bild (2015). Wer ist der Mann, der Jauch zum Schweigen brachte? Retrieved August 24, 2016 from http://www.bild.de/news/inland/guenther-jauch/wer-ist-harald-hoeppner40617350.bild.html.

Butler, J. (2009). Frames of war: When is life grievable? London: Verso

Chouliaraki, L. (2013). The ironic spectator: Solidarity in the age of post-humanitarianism. London: Polity.

Connerton, P. (1989). How societies remember. Cambridge: Cambridge University Press.

Deutche Welle (2013). Dozens of survivors protest Lampedusa ship disaster funeral. Retrieved August 24, 2016 from http://www.dw.com/en/dozens-of-survivors-protestlampedusa-ship-disaster-funeral/a-17174143. 
Erll A., \& Rigney, A. (2012). Introduction: Cultural memory and its dynamics. In A Erll \& A Rigney (eds.) Mediation, remediation, and the dynamics of cultural memory, (pp. 111). Berlin: De Gruyter.

Estefanos, M. (2016). Research interview with Karina Horsti. Stockholm April 29, 2016. Gangi, M. (2015). Catania, I 17 migranti di Lampedusa trovano finalmente degna sepoltura. Retrieved August 24, 2016 from http://www.sudpress.it/catania-finalmente-seppelliscei-17-migranti-naufragati-a-largo-di-lampedusa/

Haverinen A. (2014). Memoria virtualis: death and mourning rituals in online environments. Turku: University of Turku.

Lagerkvist, A. (2013). New memory cultures and death: existential security in the digital memory ecology. Thanatos, 2(2). https://thanatos-journal.com/2013/12/20/thanatosvol-2-22013-media-death/Neugebauer, R. (2016). Research interview with Karina Horsti. Berlin March 15, 2016.

Neumann, K. (2000). Shifting memories: The Nazi past in the new Germany. Ann Arbor: University of Michigan Press.

Nicolini G. (2015). Research interview with Ilaria Tucci. Lampedusa 4 October 2013.

Nora, P. (1989). Between memory and history: Les lieux de mémoire. Representations, 26, 726.

Papacharissi, Z. (2011). Conclusion: A networked self. In Z Papacharissi (ed.) A networked self: Identity, community, and culture on the social network sites, (pp. 304-318). London: Routledge.

Rothberg, M. (2010). Introduction: Between memory and memory. From lieux de mémoire to noeuds de mémoire. Yale French Studies, 118/119, 3-12.

Ryan, L. (2011). Memory, power and resistance: The anatomy of a tripartite relationship. Memory Studies, 4(2), 154-169.

Rygiel, K. (2016). Dying to live: migrant deaths and citizenship politics along European borders: transgressions, disruptions, and mobilizations. Citizenship Studies, 20(5), 545560.

Sea Watch (2016). Live von der Sea-Watch 2: Mediziner Brandon über den Tod einer jungen Frau · Crew 7. Retrieved August 24, 2016 from http://sea-watch.org/live-von-der-seawatch-2-mediziner-brandon-ueber-den-tod-einer-jungen-frau-\% $\% 2 \% \mathrm{~B} 7$-crew-7/.

Stierl, M. (2016). Contestations in death: the role of grief in migration struggles. Citizenship Studies, 20(2), 173-191. 
Sturken, M. (1997). Tangled Memories: The Vietnam War, the AIDS epidemic and the politics of remembering. Los Angeles: University of California Press.

Sumiala, J. (2013). Media and ritual: death, community and everyday life. London: Routledge.

UNHCR (2016). Global Focus: Eritrea. Retrieved August 24, 2016 from http://reporting.unhcr.org/node/10317\#_ga=1.146340596.1373754803.1471508700.

Weber, L. \& Pickering, S. (2011). Globalization and borders: death at the global frontier. London: Palgrave. 